\title{
Use of FAO food balance sheets to estimate the potential ability of novel folate-enriched eggs to increase the folate supply in European Union countries
}

\author{
Tony Sheehy, ${ }^{1, *}$ and Sangita Sharma ${ }^{2}$ \\ ${ }^{1}$ School of Food and Nutritional Sciences, University College Cork, Republic of Ireland: ${ }^{2}$ Department of \\ Medicine, University of Alberta, Edmonton, Alberta, Canada
}

Submitted 28 April 2010: Accepted 1 July 2010: First published online 31 August 2010

\begin{abstract}
Objective: European governments have yet to introduce mandatory folic acid fortification of foods for neural tube defect prevention because of uncertainty about the long-term safety of high intake of folic acid. Novel folate-enriched eggs have been proposed as offering a practical way of increasing intake of natural folates, which do not have the same safety concerns as synthetic folic acid. Our objective was to estimate the potential increase in folate supply that could occur in European Union (EU) countries if normal eggs were replaced by folate-enriched eggs.

Design: FAOSTAT data on daily per capita availability of eggs were linked to mean folate concentrations of un-enriched and folate-enriched eggs from three representative feeding trials from the recent literature.

Setting: Data were collated in Microsoft Excel.

Subjects: The study used food balance sheets for Europe for 1961-2003 and for twenty-six individual EU countries for 2003.

Results: There has been little variation in egg supply in Europe over the past 40 years, with eggs providing only about $1 \cdot 3-1 \cdot 6 \%$ of total energy. In 2003 , the average per capita egg supply across twenty-six EU countries was $32 \cdot 8 \mathrm{~g} / \mathrm{d}$, equivalent to a little over half an egg. Even if the folate concentrations of all eggs across the EU were increased two- to threefold, per capita folate supply would increase only by about $25 \mu \mathrm{g} / \mathrm{d}$.

Conclusions: At current enrichment levels, the availability of novel folate-enriched eggs will have little impact on folate supply in EU countries. In the absence of mandatory fortification, additional natural folate sources are needed urgently.
\end{abstract}

Keywords

Folate-enriched eggs

Folate supply

Food balance sheets
On account of the critical role played by folate in preventing neural tube defects (NTD) ${ }^{(1-4)}$, health authorities since the early 1990s have recommended that women who could become pregnant should increase their dietary folate intake and take a daily supplement of $400 \mu \mathrm{g}$ of folic acid, the synthetic form of the vitamin ${ }^{(5-7)}$. Unfortunately, compliance with this advice has been poor ${ }^{(8-14)}$, and this fact, plus the recognition that as many as $50 \%$ of all pregnancies are unplanned ${ }^{(15)}$ and unlikely to be protected, has led governments in the USA, Canada, Chile and other countries to introduce mandatory folic acid fortification of grain products $^{(16-19)}$. These policies have succeeded in reducing NTD occurrence by approximately $20-50 \%{ }^{(20-24)}$ and may also have reduced stroke-related mortality in the general population $^{(25,26)}$, as well as having had some benefit against CHD through their effect on lowering homocysteine ${ }^{(27)}$.

In spite of the success of mandatory folic acid fortification for NTD prevention, and despite calls by some experts $^{(28-31)}$ to increase fortification levels, European governments have yet to introduce such policies ${ }^{(13,32)}$. Indeed, in some European countries, even voluntary folic acid fortification is prohibited ${ }^{(12)}$. This reluctance to legislate for mandatory fortification is due to an ongoing debate about the long-term safety of exposing the general population to high intake of folic acid ${ }^{(33-36)}$. The debate centres around two main issues, namely whether high folic acid intake could promote the formation of colorectal tumours in patients with undiagnosed pre-malignant and malignant lesions ${ }^{(37-40)}$, and whether they could mask the appearance of vitamin $\mathrm{B}_{12}$ deficiency anaemia while still allowing the irreversible neurological manifestations of the deficiency to progress ${ }^{(41,42)}$.

On account of this uncertainty, attention has been directed at other strategies that might help increase population intake of natural folates, which do not carry with them the same safety concerns as synthetic folic acid. These strategies include the development of novel foods enriched with natural folates ${ }^{(12)}$. Recently, several groups 
have shown that the folate content of eggs can be increased significantly by supplementing the diet of laying hens with folic acid ${ }^{(43-48)}$. Most of the additional folate appears in the eggs in the natural form, mainly as 5 -methyltetrahydrofolate ${ }^{(48)}$. It was proposed that folateenriched eggs could offer a practical means of increasing folate intake in the general population, especially where there was limited or no access to folic acid-fortified foods ${ }^{(48)}$. The opportunity to specifically market folateenriched eggs to women of childbearing age was also suggested $^{(44)}$. To date, however, the potential impact of such products on folate intake or supply in the European Union (EU) has not been evaluated.

FAO produces annual food balance sheets that provide data on the overall per capita supply of commodities within countries. These data can be used to investigate the effect of changing the concentration of a nutrient in a commodity on nutrient supply at the national level. In the case of eggs, multiplying the daily per capita supply of eggs by their average folate concentration provides an indication of the amount of folate being provided by eggs. The effect of increasing egg folate concentrations through dietary enrichment can then be estimated. The objectives of the present study are: (i) to evaluate the trends in egg supply across Europe between 1961 and 2003; (ii) to determine the contribution made by normal un-enriched eggs to folate supply in EU countries in 2003; and (iii) to estimate the potential increase in folate supply that could be achieved if normal eggs were replaced by folate-enriched eggs.

\section{Experimental methods}

Annual food balance sheets for the European continent for the years 1961-2003 and the latest available (2003) food balance sheets for twenty-six individual EU countries were downloaded from the FAOSTAT database ${ }^{(49)}$. Data for
Luxembourg were unavailable. For each country, per capita energy supply $(\mathrm{MJ} / \mathrm{d})$, per capita egg supply $(\mathrm{g} / \mathrm{d})$ and energy from eggs (\% of total energy) were collated on a Microsoft Excel ${ }^{\circledR}$ spreadsheet (Microsoft Corporation, Redmond, WA, USA). The folate concentrations of unenriched and folate-enriched eggs from three representative hen-feeding studies from the recent literature were used to calculate the potential ability of folate-enriched eggs to increase the daily per capita folate supply in each country. The folate concentrations used in this simulation were: 30.5 and $85 \cdot 4 \mu \mathrm{g} / 100 \mathrm{~g}$ (House et al. ${ }^{(44)}$ ), $29 \cdot 6$ and $79 \mu \mathrm{g} / 100 \mathrm{~g}$ (Hebert et al. ${ }^{(45)}$ ) and 64 and $150 \mu \mathrm{g} / 100 \mathrm{~g}$ (Hoey et $a l .{ }^{(48)}$ ).

\section{Results and discussion}

Figure 1 shows the trend in per capita egg supply, expressed as energy $(\mathrm{kJ} / \mathrm{d})$ from eggs, across Europe between 1961 and 2003. Per capita egg supply increased from $163 \mathrm{~kJ} / \mathrm{d}$ in 1961 to a maximum of $224 \mathrm{~kJ} / \mathrm{d}$ in 1982 . Between 1982 and 1996, this figure decreased to $190 \mathrm{~kJ} / \mathrm{d}$. However, in recent years, the trend has begun to rise again. Overall, the contribution of eggs to total energy supply in Europe has shown little variation, fluctuating between $1.3 \%$ and $1.6 \%$.

The FAO food balance sheets for 2003 for twenty-six individual EU countries revealed that per capita energy supply ranged from $11.6 \mathrm{MJ} / \mathrm{d}$ in Slovakia to $15.7 \mathrm{MJ} / \mathrm{d}$ in Portugal, with a mean of $14 \cdot 2 \mathrm{MJ} / \mathrm{d}$ (data not shown). Similarly, per capita egg supply ranged from $18 \cdot 1 \mathrm{~g} / \mathrm{d}$ in the Republic of Ireland to $47 \cdot 8 \mathrm{~g} / \mathrm{d}$ in Denmark with a mean of $32 \cdot 8 \mathrm{~g} / \mathrm{d}$. This is equivalent to a little over half an egg. The mean contribution of eggs to total energy supply in these twenty-six countries in 2003 was $1.4 \%$.

Figure 2 shows that if the egg supply in each of these countries consisted entirely of folate-enriched eggs, this would provide approximately $41.5 \mu \mathrm{g}$ folate/d per capita,

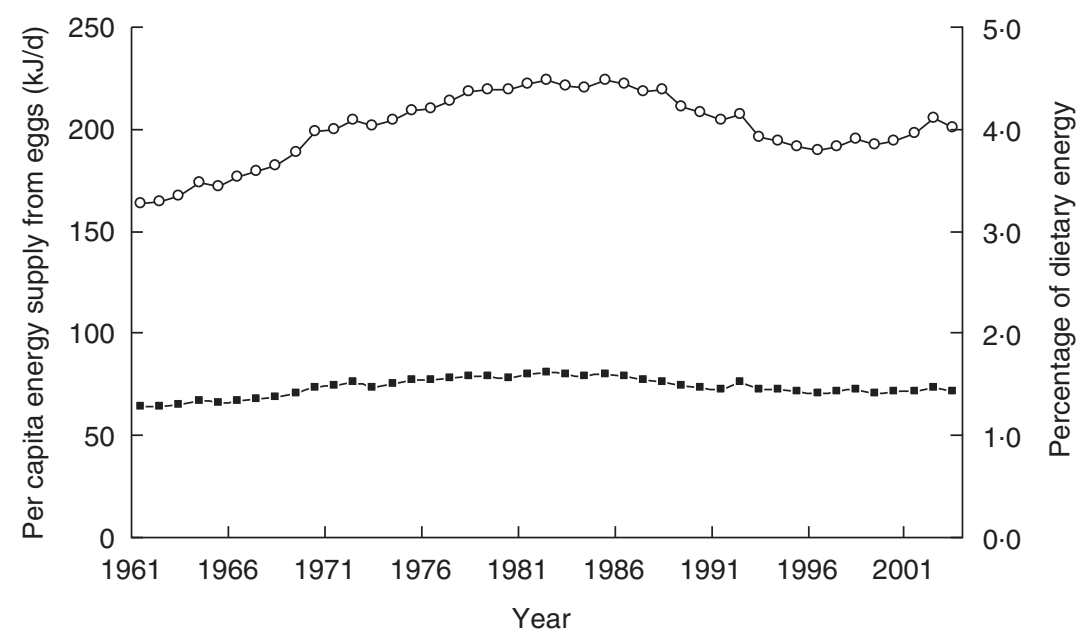

Fig. 1 Daily per capita egg supply on the European continent between 1961 and 2003. Data are expressed as per capita energy (kJ/d) from eggs $(-\mathrm{O}-)$ and as percentage of total dietary energy $(-\square-)$ supply (FAOSTAT $\left.{ }^{(49)}\right)$ 


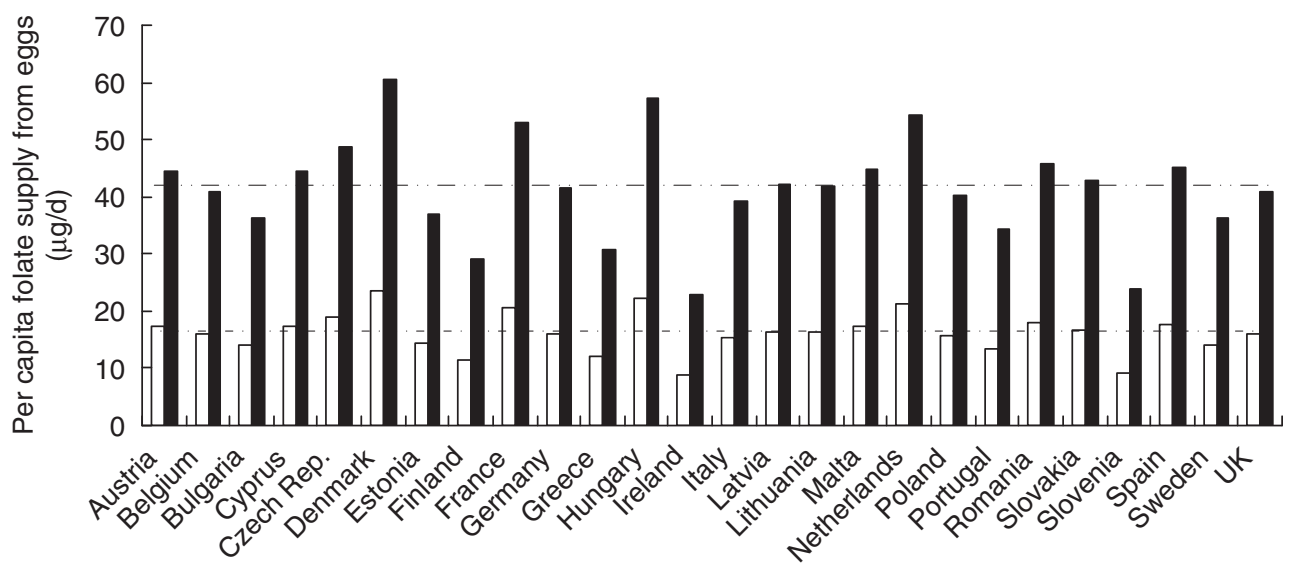

Fig. 2 Potential contribution $(\mu \mathrm{g} / \mathrm{d})$ of un-enriched $(\square)$ and folate-enriched $(\boldsymbol{\square})$ eggs to per capita folate supply in twenty-six European Union countries (FAOSTAT ${ }^{(49)}$ )

compared with $16 \cdot 2 \mu \mathrm{g} / \mathrm{d}$ per capita from un-enriched eggs, a difference of $25 \cdot 4 \mu \mathrm{g} / \mathrm{d}$. For Ireland, which has a relatively high ${ }^{(50)}$ (albeit declining ${ }^{(51)}$ ) rate of NTD and where a government decision to mandate folic acid addition to bread has been postponed pending further safety evaluations ${ }^{(52,53)}$, the potential increase in folate supply would be only $14 \mu \mathrm{g} / \mathrm{d}$. For the UK, where NTD affect 700-900 pregnancies a year and where mandatory fortification, having previously been rejected ${ }^{(54)}$, is back on the political agenda ${ }^{(55)}$, the potential increase would be $25 \cdot 1 \mu \mathrm{g} / \mathrm{d}$. The biggest effect would occur in Denmark, where folate supply would increase by some $36 \cdot 9 \mu \mathrm{g} / \mathrm{d}$.

Data from dietary intake studies provide supportive evidence that folate-enriched eggs would have a relatively minor impact on folate intake at a population level. Mean egg consumption in Irish adults in the late 1990s was only $17 \mathrm{~g} / \mathrm{d}^{(56)}$. Allowing for the folate concentration of raw eggs $(50 \mu \mathrm{g} / 100 \mathrm{~g})^{(57)}$, this implies that eggs provided only about $8.5 \mu \mathrm{g}$ folate/d or $3 \%$ of overall folate intake ${ }^{(58)}$. In the USA, mean dietary folate intake in adults before mandatory folic acid fortification was $283 \cdot 4 \mu \mathrm{g} / \mathrm{d}^{(59)}$. Eggs accounted for $5 \cdot 1 \%$ of folate intake ${ }^{(60)}$ or about $14 \mu \mathrm{g} / \mathrm{d}$. In a small cross-sectional study of ninety-five young Canadian women aged 18-25 years, eggs contributed only $1.9 \%$ of dietary folate intake or about $6 \mu \mathrm{g} / \mathrm{d}^{(61)}$. These data suggest that even if the folate content of the entire egg supply could be enriched two- to threefold (the levels that have been achieved experimentally in feeding trials), the overall contribution to folate intake at a population level would only be about $10-40 \mu \mathrm{g} / \mathrm{d}$. By comparison, the US mandatory folic acid fortification policy was designed to provide an extra $100 \mu \mathrm{g}$ folic acid/d, although, according to some reports ${ }^{(62-64)}$, it appears to have contributed about twice that amount.

In addition to the effects of folate-enriched eggs on per capita folate supply, it is important to consider their potential contribution if they were marketed specifically towards women of childbearing age. Hoey et al. ${ }^{(48)}$ stated that consumption each day of one of the enriched eggs from their studies could provide an extra $75 \mu \mathrm{g}$ of folate. Likewise, Roth-Maier and Böhmer ${ }^{(46)}$ reported that one enriched egg can provide up to $76 \mu \mathrm{g}$ folate. The latter authors determined egg folate bioavailability in a pig model system to be $68 \%$. Assuming that bioavailability is the same in man, then one fortified egg could deliver up to $52 \mu \mathrm{g}$ of bioavailable folate. However, folic acid bioavailability from fortified foods is about $85 \%{ }^{(65)}$, which suggests that it would be necessary to eat about $1 \cdot 6$ folate-enriched eggs per day to obtain the same amount of folate as would be provided by a mandatory folic acid fortification policy modelled on that of the USA.

The promotion of eggs as a source of folate raises questions about the potential for conflict with consumer attitudes towards cholesterol and with dietary guidelines that emphasise reducing energy, total fat, saturated fat and sodium. Song and Kerver ${ }^{(66)}$ analysed the data from the National Health and Nutrition Examination Survey (NHANES) III and reported that folate intake in US egg consumers was $22 \mu \mathrm{g} / \mathrm{d}$ higher than in non-consumers. However, egg consumers also had significantly higher intake of cholesterol $(>360 \mathrm{mg} / \mathrm{d})$, energy $(>1172 \mathrm{~kJ} / \mathrm{d})$, fat $(>22 \mathrm{~g} / \mathrm{d})$, saturated fat $(>6.8 \mathrm{~g} / \mathrm{d})$ and sodium $(>520 \mathrm{mg} / \mathrm{d})$. Eggs are a major source of cholesterol, with an average egg providing about $385 \mathrm{mg}^{(57)}$. Although many countries do not have quantitative thresholds for cholesterol intake ${ }^{(67)}$, the US dietary guidelines continue to recommend limiting cholesterol intake in the general public to less than $300 \mathrm{mg} / \mathrm{d}$ and $200 \mathrm{mg} / \mathrm{d}$ in the case of individuals with elevated LDL cholesterol ${ }^{(68)}$. A similar recommendation is made by the American Diabetes Association, while the National Cholesterol Education Program and the American Heart Association call for limits of $<200 \mathrm{mg} / \mathrm{d}$ and $<300 \mathrm{mg} / \mathrm{d}$, respectively ${ }^{(69)}$. Although these recommendations have been questioned because of the fact that dietary cholesterol has much less of an influence on plasma cholesterol than total fat and especially saturated and trans fat ${ }^{(70,71)}$, the general public is unaware of this and may tend to regard all high-cholesterol foods, 
including eggs, with suspicion. This situation may be exacerbated by the high-profile marketing of novel cholesterol-lowering foods, the recent EU approval of a cholesterol-related health claim for plant sterols and stanols $^{(72)}$ and by the increased tendency for doctors to prescribe statin drugs to aggressively lower serum cholesterol $^{(73)}$. Thus, it may be difficult to persuade the general public to increase egg consumption appreciably regardless of the purported health benefits.

A limitation of the present study is the fact that the results are estimates of per capita folate supply based on food balance sheet data. However, they are more likely to overstate rather than understate the true potential of folateenriched eggs because food balance sheets do not take into account food wasted after purchase ${ }^{(74)}$. In addition, the estimates are based on the assumption that all eggs available for consumption within each country are folate enriched, whereas in the absence of strong incentives to egg producers it is difficult to imagine this situation ever occurring. Finally, even if poultry feed manufacturers were to add overages to their feeds, it probably would not have any additional benefit because egg folate concentrations appear to be saturable after a critical level ${ }^{(43-45,47,48)}$.

In conclusion, the present study has shown that because of the low supply of eggs in the EU, even enriching the folate concentration of the entire egg supply two- to threefold would only increase per capita folate supply by about $25 \mu \mathrm{g} / \mathrm{d}$. If targeted at individuals (e.g. women of childbearing age) and consumed daily, folate-enriched eggs could provide useful amounts of natural folates. However, the apparently lower folate bioavailability from folate-enriched eggs compared with fortified foods must be considered. Whether the public could be persuaded to consume these novel products in the required amounts is questionable because of the relatively static egg supply patterns that have persisted throughout Europe for over 40 years and because of possible conflicts with dietary guidelines and consumer attitudes regarding cholesterol. In the light of the continuing reluctance of EU governments to introduce mandatory folic acid fortification, further research is urgently required on other ways of increasing natural folate intake within EU countries.

\section{Acknowledgements}

This research received no specific grant from any funding agency in the public, commercial or not-for-profit sectors. The authors declare that they have no conflicts of interest. The authors express their sincere gratitude to FAOSTAT, Statistics Division, Food and Agriculture Organization of the UN, for allowing them to use their data. T.S. and S.S. conceived the study. T.S. acquired and interpreted the data and drafted the paper. S.S. revised the paper critically for important intellectual content. Both authors approved the final version of the paper.

\section{References}

1. MRC Vitamin Study Research Group (1991) Prevention of neural tube defects: results of the Medical Research Council Vitamin Study. Lancet 338, 131-137.

2. Czeizel AE \& Dudás I (1992) Prevention of the first occurrence of neural-tube defects by periconceptional vitamin supplementation. $N$ Engl J Med 327, 1832-1835.

3. Werler MM, Shapiro S \& Mitchell AA (1993) Periconceptional folic acid exposure and risk of occurrent neural tube defects. JAMA 269, 1257-1261.

4. Berry RJ, Li Z, Erickson JD et al. (1999) Prevention of neural-tube defects with folic acid in China. China-US Collaborative Project for Neural Tube Defect Prevention. $N$ Engl J Med 341, 1485-1490.

5. Department of Health Expert Advisory Group (1992) Folic Acid and the Prevention of Neural Tube Defects. London: Department of Health.

6. Centers for Disease Control (1992) Recommendations for the use of folic acid to reduce the number of cases of spina bifida and other neural tube defects. MMWR Recomm Rep 41, 1-7.

7. National Health and Medical Research Council (1993) Revised Statement on the Relationship Between Dietary Folic Acid and Neural Tube Defects such as Spina Bifida. 115th Session. Canberra: NHMRC.

8. Clark NA \& Fisk NM (1994) Minimal compliance with the Department of Health recommendation for routine folate prophylaxis to prevent fetal neural tube defects. BrJ Obstet Gynaecol 101, 709-710.

9. Bailey LB, Rampersaud GC \& Kauwell GP (2003) Folic acid supplements and fortification affect the risk for neural tube defects, vascular disease and cancer: evolving science. J Nutr 133, 1961S-1968S.

10. Knudsen VK, Orozova-Bekkevold I, Rasmussen LB et al. (2004) Low compliance with recommendations on folic acid use in relation to pregnancy: is there a need for fortification? Public Health Nutr 7, 843-850.

11. Busby A, Abramsky L, Dolk H et al. (2005) Preventing neural tube defects in Europe: a missed opportunity. Reprod Toxicol 20, 393-402.

12. Buttriss J (2005) Strategies designed to increase awareness about folates and health, and to increase folate intake: a review. Trends Food Sci Technol 16, 246-252.

13. Stoll C, Alembik Y \& Dott B (2006) Are the recommendations on the prevention of neural tube defects working? Eur J Med Genet 49, 461-465.

14. Forster DA, Wills G, Denning A et al. (2009) The use of folic acid and other vitamins before and during pregnancy in a group of women in Melbourne, Australia. Midwifery 25, 134-146.

15. Grimes DA (1986) Unplanned pregnancies in the United States. Obstet Gynecol 67, 438-442.

16. Food and Drug Administration (1996) Food standards: amendment of standards of identity for enriched grain products to require addition of folic acid. Final rule. 21 CFR Parts 136, 137 and 139. Federal Register 61, 8781-8807.

17. Health Canada (1997) Regulations amending the Food and Drug Regulations (1066). Canada Gazette Part 1 131, 3702-3737.

18. Freire WB, Hertrampf E \& Cortés F (2000) Effect of folic acid fortification in Chile: preliminary results. Eur $J$ Paediatr Surg 10, Suppl. 1, 42-43.

19. Bell KN \& Oakley GP Jr (2009) Update on prevention of folic acid-preventable spina bifida and anencephaly. Birth Defects Res A Clin Mol Teratol 85, 102-107.

20. Honein MA, Paulozzi LJ, Mathews TJ et al. (2001) Impact of folic acid fortification of the US food supply on the occurrence of neural tube defects. JAMA 285, 2981-2986. 
21. Williams LJ, Mai CT, Edmonds LD et al. (2002) Prevalence of spina bifida and anencephaly during the transition to mandatory folic acid fortification in the United States. Teratology 66, 33-39.

22. Mills JL \& Signore C (2004) Neural tube defect rates before and after food fortification with folic acid. Birth Defects Res A Clin Mol Teratol 70, 844-845.

23. López-Camelo JS, Orioli IM, da Graça Dutra M et al. (2005) Reduction of birth prevalence rates of neural tube defects after folic acid fortification in Chile. Am J Med Genet A 135 120-125.

24. Hertrampf E \& Cortés F (2008) National food-fortification program with folic acid in Chile. Food Nutr Bull 29, 2 Suppl., S231-S237.

25. Yang Q, Botto LD, Erickson JD et al. (2006) Improvement in stroke mortality in Canada and the United States, 1990 to 2002. Circulation 113, 1335-1343.

26. Wang X, Qin X, Demirtas H et al. (2007) Efficacy of folic acid supplementation in stroke prevention: a metaanalysis. Lancet 369, 1876-1882.

27. Wald DS, Morris JK, Law M et al. (2006) Folic acid, homocysteine, and cardiovascular disease: judging casuality in the face of inconclusive trial evidence. BMJ $\mathbf{3 3 3}$, 1114-1117.

28. Brent RL \& Oakley GP Jr (2005) The Food and Drug Administration must require the addition of more folic acid in 'enriched' flour and other grains. Pediatrics 116, 753-755.

29. Bar-Oz B, Koren G, Nguyen P et al. (2008) Folate fortification and supplementation - are we there yet? Reprod Toxicol 25, 408-412.

30. Oakley GP Jr (2007) When will we eliminate folic acidpreventable spina bifida? Epidemiology 18, 367-368.

31. Bentley TG, Weinstein MC, Willett WC et al. (2009) A costeffectiveness analysis of folic acid fortification policy in the United States. Public Health Nutr 12, 455-467.

32. Wald NJ (2004) Folic acid and the prevention of neuraltube defects. N Engl I Med 350, 101-103.

33. Wright AJA, Finglas PM \& Southon S (2001) Proposed mandatory fortification of the UK diet with folic acid: have potential risks been underestimated? Trends Food Sci Technol 12, 313-321.

34. Shane B (2003) Folate fortification: enough already? Am J Clin Nutr 77, 8-9.

35. Hubner RA, Houlston RD \& Muir KR (2007) Should folic acid fortification be mandatory? No. BMJ 334, 1253.

36. Lucock M \& Yates Z (2009) Folic acid fortification: a double-edged sword. Curr Opin Clin Nutr Metab Care 12 , 555-564.

37. Kim YI (2004) Will mandatory folic acid fortification prevent or promote cancer? Am J Clin Nutr 80, 1123-1128.

38. Cole BF, Baron JA, Sandler RS et al. (2007) Folic acid for the prevention of colorectal adenomas: a randomized clinical trial. JAMA 297, 2351-2359.

39. Mason JB, Dickstein A, Jacques PF et al. (2007) A temporal association between folic acid fortification and an increase in colorectal cancer rates may be illuminating important biological principles: a hypothesis. Cancer Epidemiol Biomarkers Prev 16, 1325-1329.

40. Hirsch S, Sanchez H, Albala C et al. (2009) Colon cancer in Chile before and after the start of the flour fortification program with folic acid. Eur J Gastroenterol Hepatol 21, 436-439.

41. Scott JM (1999) Folate and vitamin B12. Proc Nutr Soc 58, 441-448.

42. Morris MS, Jacques PF, Rosenberg IH et al. (2007) Folate and vitamin B-12 status in relation to anemia, macrocytosis, and cognitive impairment in older Americans in the age of folic acid fortification. Am J Clin Nutr 85, 193-200.
43. Sherwood TA, Alphin RL, Saylor WW et al. (1993) Folate metabolism and deposition in eggs by laying hens. Arch Biochem Biophys 307, 66-72.

44. House JD, Braun K, Balance DM et al. (2002) The enrichment of eggs with folic acid through supplementation of the laying hen diet. Poult Sci 81, 1332-1337.

45. Hebert K, House JD \& Guenter W (2005) Effect of dietary folic acid supplementation on egg folate content and the performance and folate status of two strains of laying hens. Poult Sci 84, 1533-1538.

46. Roth-Maier DA \& Böhmer BM (2007) Fortification of eggs with folic acid as a possible contribution to enhance the folic acid status of populations. Int J Vitam Nutr Res 77, 297-301.

47. Bunchasak C \& Kachana S (2009) Dietary folate and vitamin B12 supplementation and consequent vitamin deposition in chicken eggs. Trop Anim Health Prod 41, 1583-1589.

48. Hoey L, McNulty H, McCann EME et al. (2009) Laying hens can convert high doses of folic acid added to the feed into natural folates in eggs providing a novel source of food folate. Br J Nutr 101, 206-212.

49. FAOSTAT (2009) Statistics Division, Food and Agriculture Organisation of the UN. http://faostat.fao.org/site/368/ DesktopDefault.aspx?PageID $=368$ \#ancor (accessed June 2009).

50. EUROCAT (1987) Prevalence of neural tube defects in 16 regions of Europe, 1980-1983. The EUROCAT Working Group. Int J Epidemiol 16, 246-251.

51. Cotter AM \& Daly SF (2005) Neural tube defects: is a decreasing prevalence associated with a decrease in severity? Eur J Obstet Gynecol Reprod Biol 119, 161-163.

52. Food Safety Authority of Ireland (2008) Report of the Implementation Group on Folic Acid Food Fortification to the Department of Health and Children. Dublin: Food Safety Authority of Ireland; available at http://staging. fsai.ie/WorkArea/linkit.aspx?LinkIdentifier $=$ id\&ItemID $=7602$

53. Sweeney MR, Staines A, Daly L et al. (2009) Persistent circulating unmetabolised folic acid in a setting of liberal voluntary folic acid fortification. Implications for further mandatory fortification? BMC Public Health 9, 295.

54. Food Standards Agency (2002) Agency Advice to Health Ministers on Folic Acid and the Prevention of Disease. Annex A. London: Food Standards Agency; available at http://www.food.gov.uk/multimedia/pdfs/folicacid_disease_ annexa.pdf

55. Scientific Advisory Committee on Nutrition (2009) Folic Acid and Colorectal Cancer Risk: Review of Recommendations for Mandatory Folic Acid Fortification. London: Scientific Advisory Committee on Nutrition; available at http://www.sacn.gov.uk/pdfs/summary_of_sacn_report_to_ cmo_19_october_2009.pdf

56. Irish Universities Nutrition Alliance (2001) North/South Ireland Food Consumption Survey. Summary Report. Dublin: Irish Universities Nutrition Alliance; available at http://www.iuna.net/docs/tables21_226.pdf

57. Food Standards Agency (2002) McCance and Widdowson's Composition of Foods, 6th ed. London: Her Majesty's Stationary Office/Office of Public Sector Information.

58. O'Brien MM, Kiely M, Harrington KE et al. (2001) The North/South Ireland Food Consumption Survey: vitamin intakes in 18-64-year-old adults. Public Health Nutr 4, 1069-1079.

59. Ford ES \& Ballew C (1998) Dietary folate intake in US adults: findings from the third National Health and Nutrition Examination Survey. Ethn Dis 8, 299-305.

60. Applegate E (2000) Introduction: nutritional and functional roles of eggs in the diet. J Am Coll Nutr 19, 495S-498S.

61. Shuaibi AM, House JD \& Sevenhuysen GP (2008) Folate status of young Canadian women after folic acid fortification of grain products. J Am Diet Assoc 108, 2090-2094. 
62. Rader JI, Weaver CM \& Angyal G (2000) Total folate in enriched cereal grain products in the United States following fortification. Food Chem 70, 275-289.

63. Choumenkovitch SF, Selhub J, Wilson PW et al. (2002) Folic acid intake from fortification in United States exceeds predictions. J Nutr 132, 2792-2798.

64. Quinlivan EP \& Gregory JF III (2003) Effect of food fortification on folic acid intake in the United States. $A m \mathrm{~J}$ Clin Nutr 77, 221-225.

65. Suitor CW \& Bailey LB (2000) Dietary folate equivalents: interpretation and application. J Am Diet Assoc 100, 88-94.

66. Song WO \& Kerver JM (2000) Nutritional contribution of eggs to American diets. J Am Coll Nutr 19, 556S-562S.

67. Life Sciences Research Office (2006) The Scientific Evidence and Approach Taken to Establish Guidelines for Cholesterol Intake in Australia, Canada, the United Kingdom, and the United States. Executive Summary. Bethesda, MD: LRSO.

68. US Department of Health and Human Services (2005) Dietary Guidelines for Americans, Chapter 6: Fats. http:// www.health.gov/dietaryguidelines/dga2005/document/html/ chapter6.htm (accessed July 2009).

69. Krebs-Smith SM \& Kris-Etherton P (2007) How does MyPyramid compare to other population-based recommendations for controlling chronic disease? J Am Diet Assoc 107, 830-837.

70. McNamara DJ (2000) The impact of egg limitations on coronary heart disease risk: do the numbers add up? J Am Coll Nutr 19, 540S-548S.

71. Kritchevsky SB \& Kritchevsky D (2000) Egg consumption and coronary heart disease: an epidemiologic overview. J Am Coll Nutr 19, 5 Suppl., 549S-555S.

72. Commission of the European Communities (2009) Commission Regulation (EC) No. 983/2009 of 21 October 2009 on the authorisation and refusal of authorisation of certain health claims made on food and referring to the reduction of disease risk and to children's development and health. Official Journal of the European Union 22.10.2009, L 277/3L 277/8; available at http://eur-lex.europa.eu/LexUriServ/ LexUriServ.do?uri=OJ:L:2009:277:0003:0012:EN:PDF

73. Walley T, Folino-Gallo P, Stephens P et al. (2005) Trends in prescribing and utilization of statins and other lipid lowering drugs across Europe 1997-2003. Br J Clin Pharmacol 60, 543-551.

74. Schmidhuber J \& Traill WB (2006) The changing structure of diets in the European Union in relation to healthy eating guidelines. Public Health Nutr 9, 584-595. 